\title{
GIANT INTRA-ABDOMINAL LIPOMA- AN ENIGMA
}

Bikram Haldar1, Sahid Khondaker², Bitan Kumar Chattopadhyay³

1Postgraduate Trainee, Department of General Surgery, IPGME and R, Kolkata.

2 Postgraduate Trainee, Department of General Surgery, IPGME and R, Kolkata.

3 Professor and HOD, Department of General Surgery, IPGME and R, Kolkata.

HOW TO CITE THIS ARTICLE: Haldar B, Khondaker S, Chattopadhyay BK. Giant intra-abdominal lipoma- an enigma. J. Evolution Med. Dent. Sci. 2018;7(05):697-699, DOI: 10.14260/jemds/2018/157

\section{PRESENTATION OF CASE}

A 59-year-old gentleman presented with the chief complaint of generalised abdominal distension for the last 2 years. It had achieved an uncomfortable size, which was disturbing his day-to-day activities. It was not associated with any pain, obstructive or compressive symptoms and no history of lowgrade fever, night sweats and anorexia or weight loss.

Patient's nutritional status was good, had mild pallor and bilateral pedal oedema.

On examination, the abdomen was found to be hugely distended with an inverted umbilicus (girth $160 \mathrm{~cm}$ ). No venous engorgement or pigmentation were noted. A diffuse firm lump was palpated in all quadrants of the abdomen, nontender, non-mobile, no organomegaly and no evidence of ascites. Routine investigations were within normal limits.

CT scan and USG revealed a lobulated mass with predominantly fat content and areas of soft tissue occupying most of the abdomen. It had fine septations, tiny calcifications measuring 39.4 by 36.9 by $29.1 \mathrm{~cm}$ (Fig. 1, 2).

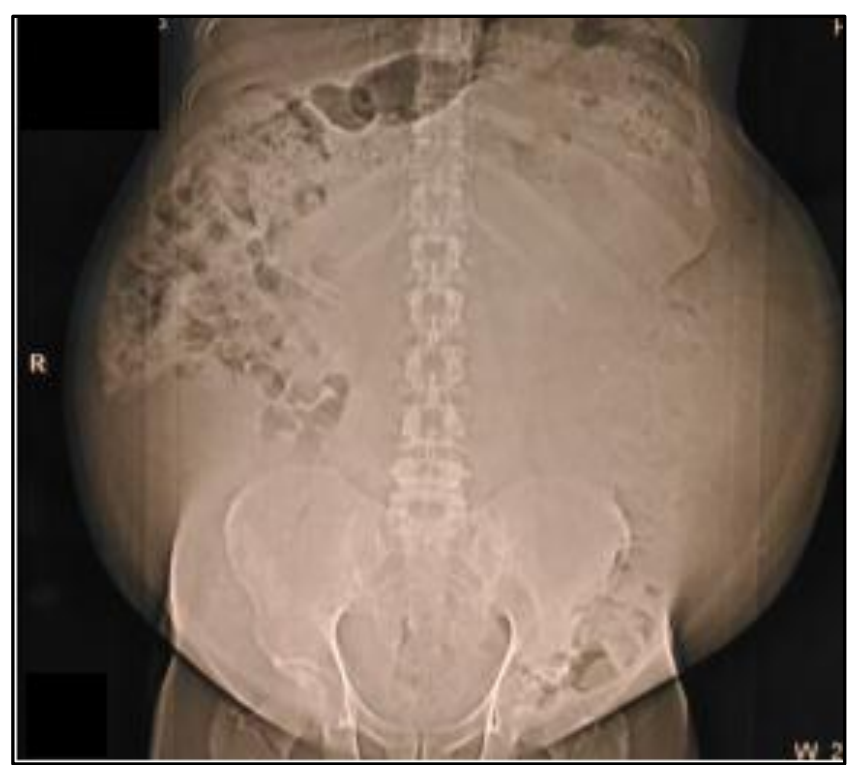

Figure 1. CT Scanogram of the Patient showing Hugely Distended Abdomen with Displaced Intestinal Loops

'Financial or Other Competing Interest': None.

Submission 19-12-2017, Peer Review 13-01-2018,

Acceptance 18-01-2018, Published 29-01-2018.

Corresponding Author:

Dr. Bikram Haldar,

\#1C1-25/5, Pranyik Housing Complex,

Thakurpukur.

Kolkata-700104.

E-mail: Bikramhaldar6883@gmail.com

DOI: $10.14260 /$ jemds $/ 2018 / 157$

\section{(c) $(7)$}

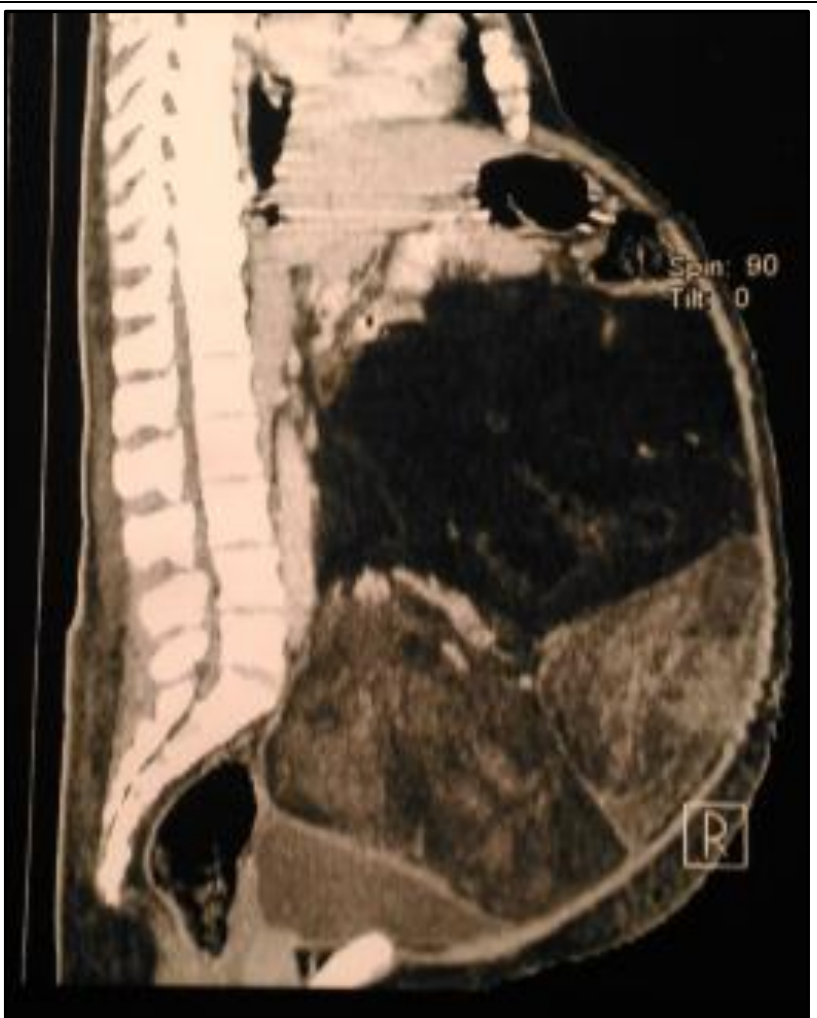

Figure 2. CECT Scan showing the Huge Intra-abdominal Lobulated Mass

\section{DIFFERENTIAL DIAGNOSES}

The possible differential diagnoses of the lump is-

a. Retroperitoneal sarcoma.

b. Mesenteric cyst.

c. Omental cyst.

\section{CLINICAL DIAGNOSIS}

Based on the clinical findings and investigations, a diagnosis of a retroperitoneal neoplasm was made.

\section{DISCUSSION OF MANAGEMENT}

DJ stenting of both ureters was done 3 days before the operation.

The abdomen was opened by a midline incision. After opening the peritoneum, a solid, yellowish, encapsulated lesion $(15 * 10 * 10 \mathrm{~cm})$ was seen in the central part of abdomen along with $2-3$ similar larger masses $(30 * 15 * 15)$ beneath it with very evident cleavage planes (Fig. 3). The small bowel was pushed towards the right hypochondrium.

The lesions were separated from the colon, kidney, ureter, inferior vena cava and abdominal aorta by very evident cleavage planes. No invasion of any major organ was noted. Mesentery was free. The capsule had adherence to the retroperitoneal tissue and had small calibre vessels on its surface. 
After the major 3 lesions were removed, smaller masses were dissected out. Total weight was $15.5 \mathrm{~kg}$ (Fig. 4). Postoperative period was uneventful.

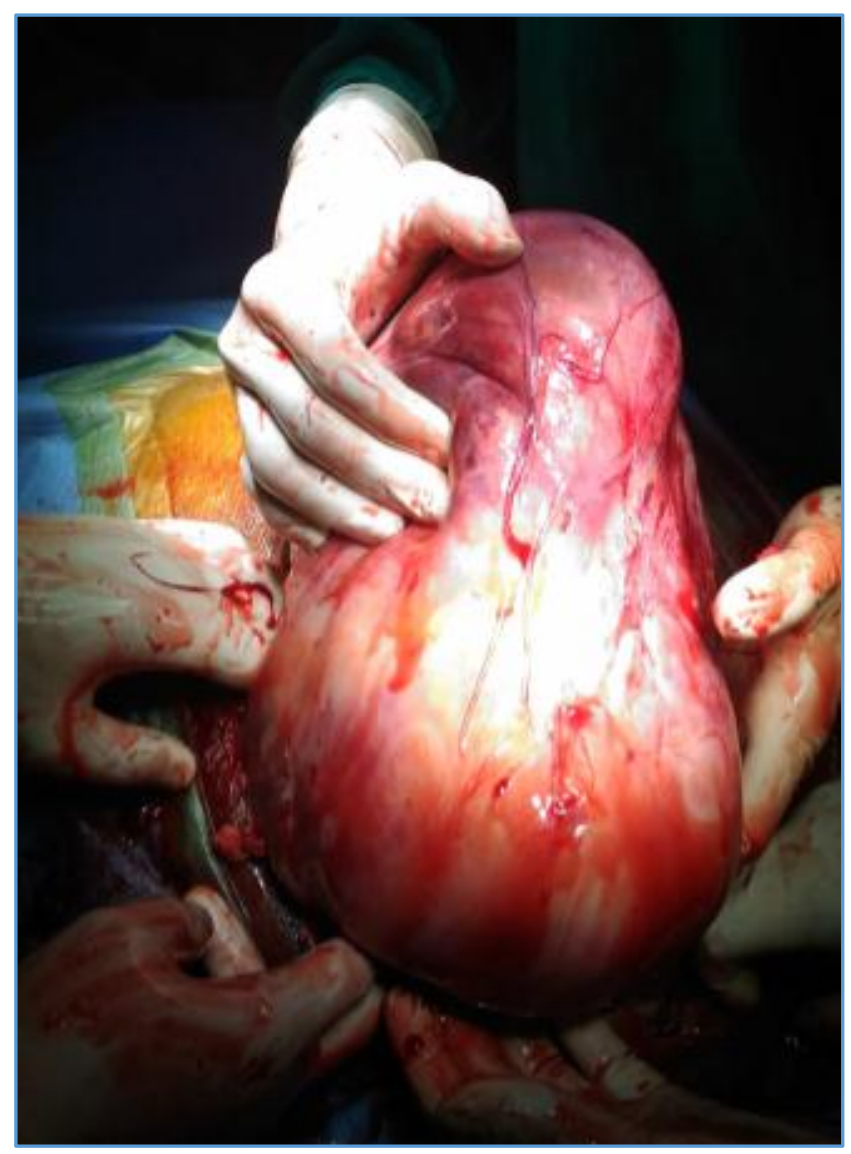

Figure 3. Intraoperative Picture showing an Encapsulated Lobule of the Mass

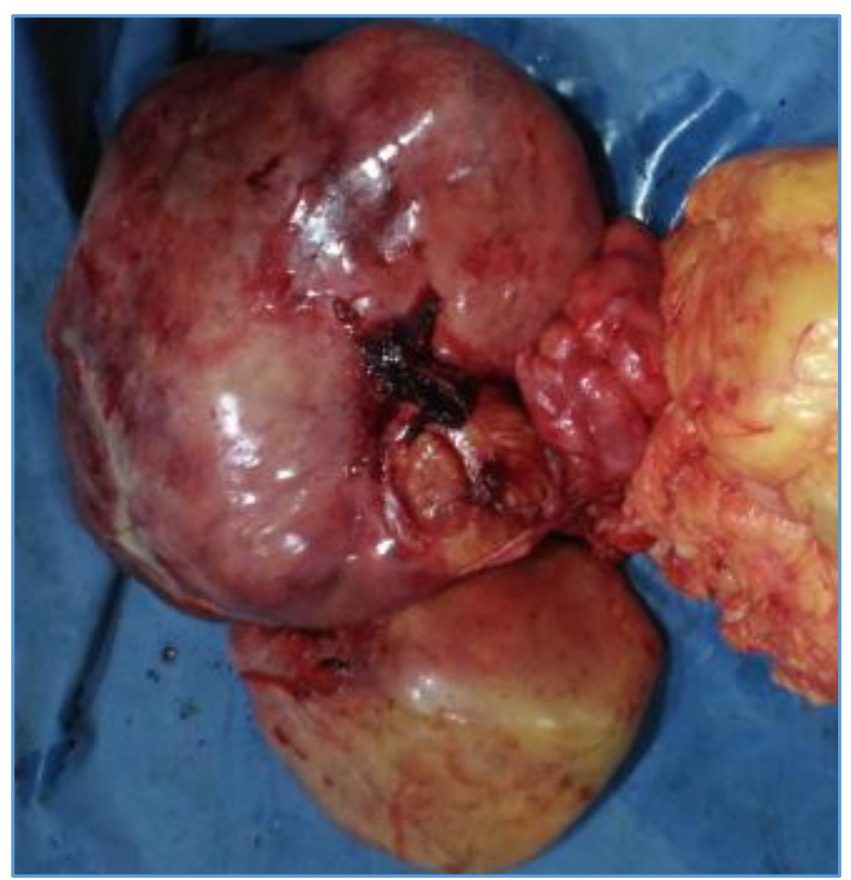

Figure 4. Entire Excised Specimen made of 3 Well-Encapsulated Lobules

\section{PATHOLOGICAL DISCUSSION}

It showed mature adipose tissues arranged in lobules with intervening septae of vascularised collagenous tissue (Fig. 5). Secondary changes in the form of haemorrhage and spindle cells were also noted.

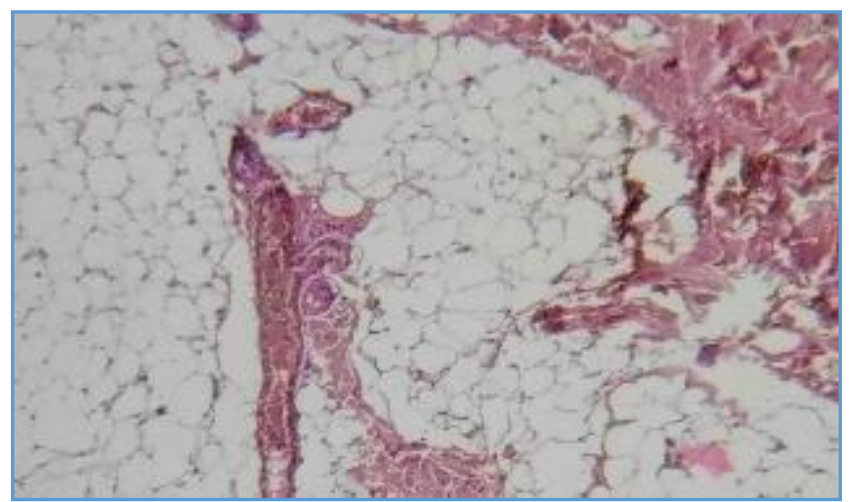

Figure 5. Histopathological Analysis showing Mature Adipocytes arranged in Lobules with Vascularised Collagenous Septae

\section{DISCUSSION}

The exact prevalence of lipomas is an enigma due to rather asymptomatic nature of the lesion. Intra-abdominal lipomas are the rarest of them all.1,2 Such tumours occur commonly in the age group above 50 yrs. and have been seen more among women. ${ }^{3}$

Literature search reveals around 30 such documented cases. Pathogenesis is rather unknown with possible factors could be obesity, diabetes mellitus, elevation of serum cholesterol, radiation, familial tendency and chromosomal abnormalities. ${ }^{4,5}$

Malignant change of lipoma to liposarcoma is almost never seen. These benign lesions may grow to large proportions and numbers, but generally do not mutate. ${ }^{6}$ Deep lipomas are noted only when they grow in larger proportions to their size, but clinical manifestations are rather rare.

Ultrasonography depicts these intra-abdominal lipomas as well-defined homogeneous, echogenic masses. Computed tomography reveals these masses with low attenuation similar to adipose tissue. ${ }^{7}$

In most of the cases complete surgical excision is easily performed, because the capsule that surrounds the tumour presents a very evident cleavage plane. ${ }^{8}$

Liposarcoma of low-grade malignancy (Grade 1) can have a similar appearance and are denominated lipomas like. ${ }^{9}$ As liposarcoma is a possibility in these lesions, so a complete surgical excision is the treatment of choice. ${ }^{10}$ Recurrence rate is less than $5 \%$ and is seen only due to incomplete excision of the mass. ${ }^{8}$

Other possible diagnoses like lipoblastoma, lymphangioma, liposarcoma or lymphangiolipoma should be considered. $^{9}$

\section{FINAL DIAGNOSIS}

The final diagnosis of the case was that of a giant intraabdominal lipoma. 


\section{REFERENCES}

[1] Ilhan H, Tokar B, Işiksoy S, et al. Giant mesenteric lipoma. J Pediatr Surg 1999;34(4):639-40.

[2] Signer RD, Bregman D, Klausner S. Giant lipoma of the mesentery: report of an unusual case and review of the literature. Am Surg 1976;42(8):595-7.

[3] Cavazza A, Giunta A, Pedrazzoli C, et al. Extrarenal retroperitoneal angiomyolipoma: description of a case and review of the literature. Pathologica 2001;93(1):44-9.

[4] Weiss SW, Goldblum JR. Enzinger and Weiss's soft tissue tumors. $5^{\text {th }}$ edn. St Louis, MO: Mosby 2007.

[5] Enzinger FM, Weiss SW. Soft tissue tumors. $3^{\text {rd }}$ edn. St. Louis, MO: Mosby 1995:384-405.

[6] Munk PL, Lee MJ, Janzen DL, et al. Lipoma and liposarcoma: evaluation using CT and MR imaging. AJR Am J Roentgenol 1997;169(2):589-94.
[7] Eresué J, Philippe JC, Casenave P, et al. La tomodensitométrie des lipomes et liposarcomes abdominaux de l'adulte. A propos de 9 cas. J Radiol 1984;65:145-9.

[8] Tani T, Abe H, Tsukada $\mathrm{H}$, et al. Lipomatosis of the ileum with volvulus: report of a case. Surg Today 1998;28(6):640-2.

[9] Lucas DR, Nascimento AG, Sanjay BK, et al. Welldifferentiated liposarcoma. The Mayo Clinic experience with 58 cases. Am J Clin Pathol 1994;102(5):677-83.

[10] Sato M, Ishida H, Konno K, et al. Mesenteric lipoma: report of a case with emphasis on US findings. Eur Radiol 2002;12(4):793-5. 